\author{
Ignac Fock
}

\title{
Tradicija, konvencija in modernost: predgovori $v$ prvem hispanoameriškem romanu
}

\author{
Ključne besede: predgovor, paratekst, El Periquillo Sarniento, hispanoameriški \\ roman, razsvetljenski roman, pikareskni roman, topos
}

DOI: 10.4312/ars.11.2.139-154

\section{Uvod}

Mehiški pisatelj in novinar José Joaquín Fernández de Lizardi (1776-1821) velja za začetnika modernega hispanoameriškega pripovedništva, njegovo najpomembnejše delo, El Periquillo Sarniento, pa literarna zgodovina šteje za prvi hispanoameriški roman. Postavljen je v okvir pikaresknega romana in priča o vplivih Don Kihota, po idejni podstati, vsebini in tonu pa je razsvetljenski roman. V njem je šest predgovorov, ki ga formalno in tematsko povezujejo s temi tremi tradicijami oziroma zgledi.

Naslov, ime avtorja, opombe, kazalo etc., pa tudi predgovor, torej vse, kar v romanu ni besedilo romana oziroma kar v literarnem delu ni delo sámo, Gérard Genette imenuje paratekst. Ta je lahko za literarno vrednost nebistven, čeprav je samoumeven (npr. platnice, kolofon, paginacija), pa vendar mu dejstvo, da predstavlja prehod oziroma po Genettu "prag« (seuil) med empirično in literarno stvarnostjo, podeljuje izjemne strateške in pragmatične razsežnosti, kar velja še posebej za predgovor. ${ }^{1} \mathrm{~V}$ konceptualnem in formalnem smislu izvira iz antičnega dramskega prologa. Nekatere njegove funkcije so odtlej ostale nespremenjene, druge pa so se razvile ali prilagodile $\mathrm{v}$ določenem obdobju ali zvrsti. Kot ustaljen retorični postopek, s katerim avtor svoje delo postavlja na oder fikcije oziroma si pridobiva bralčevo naklonjenost (captatio benevolentiae), je predgovor pogosto postal del literarne tradicije (npr. v pikaresknem in pisemskem romanu) ali pa prerasel v konvencijo in ga, vse od antičnih časov, bremenijo »unas leyes tiránicas« (Porqueras Mayo, 1957, 122).

Namen pričujočega članka je osvetliti predgovorne mehanizme v Periquillu Sarnientu in pokazati, da že predgovori postavljajo roman izven okvirov (predvsem

1 Predgovor uporabljam kot enoten termin za vse preliminarne paratekste v romanu, ki govorijo o besedilu, ki sledi - ne glede na eksplicitno poimenovanje, npr. »opozorilo (avtorja/urednika)«, "uvod «, "prolog«, "predgovor«, "pojasnilo (bralcu)« etc. Takšna raba termina predgovor bi ustrezala Genettovemu (1987) préface oziroma Porqueras Mayevemu (1957) prólogo. 
pikareskne) tradicije. Poleg tega številne funkcije teh predgovorov, ki sicer temeljijo na konvencijah in na topiki, značilni za predgovor, pričajo o modernosti Lizardijevega romana: tako idejno kakor formalno oziroma s stališča pripovedne tehnike.

\section{Literarnozgodovinski okvir}

El Periquillo Sarniento je izhajal po delih med letoma 1816 in 1817 ter doživljal uspeh bestsellerja, toda tisk predzadnjega, četrtega zvezka je cenzura prepovedala, ker obsoja suženjstvo in rasizem ter dvoličnost monarhične oblasti in njene glavne zaveznice, katoliške cerkve. Roman, katerega nastajanje sovpada s procesom osamosvajanja Mehike izpod španske krone (1810-1821), je tako v celoti izšel šele postumno leta 1830 .

Periquillo Sarniento na smrtni postelji sklene v poduk potomcem zapisati svojo življenjsko zgodbo, ki sega od začetka 70. let 18. stoletja do njegove smrti leta 1813. Pikareskni roman služi Lizardiju kot žanrski okvir razsvetljenski in (pred)revolucionarni misli ter prikazuje njuno specifičnost na ozemlju, kjer $\mathrm{v}$ neenakopravnih položajih sobivajo tri rase in ki se osvobaja izpod kolonialne oblasti. ${ }^{2}$ $\mathrm{V}$ romanu je tudi antologijski primer utopije, otok Saucheofú, ${ }^{3}$ najobsežnejši del protagonistovega razvoja pa spremlja satira kolonialne družbe: Periquillo srečuje tipske osebe vseh stanov in poklicev; kot pričevalec komentira šege in navade ${ }^{4}$ ter iz svojih prigod izlušči moralni nauk, pogosto v obliki izčrpnih digresij.

\section{Predgovori v Periquillu Sarnientu}

Prvi predgovor (I) je »Advertencia precisa« (»Nujno opozorilo«); dodan je v drugi izdaji. Njegov avtor je nedvomno Lizardi sam (Ruiz Barrionuevo, v: Lizardi, 2008, 87), torej je avtentično avktorialni. ${ }^{5}$ Drugi predgovor (II), pod katerim je podpisan El

2 Ideje enciklopedistov so prihajale v izrazito katoliško družbo v za nameček despotsko reformirani monarhiji; tudi Lizardijev laicizem odseva izključno njegova liberalna in nacionalistična prepričanja ter je strogo omejen na politično misel. Salomon $(1988,422)$ meni, da je Lizardijevo branje Rousseauja rahlo prilagojeno »con arreglo a una perspectiva de 'cristianismo ilustrado' «.

3 Za utopijo v Periquillu Sarnientu gl. Ramírez (2006) in El-Kadi (2004).

4 Tehnika opazovalca in satiričnega komentatorja družbe predstavlja tudi zametek kostumbrizma. (cf. Lamb, 1951).

5 Genette predgovore razlikuje glede na predgovorno instanco (pripovedovalec predgovora) in okoliščine nastanka. Avktorialni je predgovor, katerega domnevni avtor je tudi resnični ali domnevni avtor romana, avtentičen pa je, če to potrjujejo še drugi paratekstualni indici. Avtentično avktorialne predgovore nadalje deli na prevzemalne (préface assomptive), ker avtor prevzema odgovornost za romaneskno besedilo, in tajitvene (préface dénégative), v katerih avtor predgovora eksplicitno ali implicitno (v vsakem primeru pa »neresnicoljubno«) zanika, da bi bil tudi avtor romanesknega besedila. Te zadnje predgovore, ki jih poimenuje tudi psevdoalografski ali kriptoavktorialni, Genette prišteva med fikcijske, mednje pa sodi tudi fiktivno aktorialni predgovor (préface actoriale fictive), 
Pensador, kar je bil Lizardijev psevdonim, je tajitveni avtentično avktorialni oziroma psevdoalografski. Tretji(III) je Periquillev, torejfiktivno aktorialni. V četrtem predgovoru (IV), ki dopolnjuje predgovora (II) in (III), se avtor razglasi za Periquillevega prijatelja, ki zgolj popravlja, ureja in objavlja Periquillev rokopis, četudi jasno sliko o tem dobimo šele na koncu romana. Enako beremo v dialoškem petem predgovoru (V), zato sta (IV) in (V), tako kot (II), tajitvena avtentično avktorialna oziroma psevdoalografska. Šesti predgovor (VI) je bodisi avtentično alografski in je zanj, tako kot za postumno izdajo romana, odgovorna (resnična) tretja oseba (urednik) bodisi psevdoalografski (tako kot (II), (IV) in (V)) ter ga je Lizardi zapustil skupaj s cenzuriranim četrtim zvezkom.

\section{Avktorialni predgovori in literarna tradicija}

\subsection{Predgovor in zunajliterarna stvarnost}

"Nujno opozorilo« (I) je na prvi pogled informativne narave in le odraz zunajliterarnih okoliščin ter ima prezentativno in defenzivno funkcijo, saj opominja, kako nujno je imeti v mislih, da je bilo delo napisano in izdano v obdobju cenzure in inkvizicije pod špansko nadvlado ter da je avtor pri oblasteh padel v nemilost:

Es menester tener presente que esta obra se escribió e imprimió en el año de 1816, bajo la dominación española, estando el autor mal visto de su gobierno por patriota, sin libertad de imprenta, con sujeción a la censura de oidores, canónigos y frailes; y lo que es más que todo, con la necia y déspota Inquisición ${ }^{6}$ encima (87). ${ }^{7}$

Porqueras Mayo, ki predgovore deli po kriterijih zunanje forme in vsebine, takšnemu predgovoru (predstavitveni oziroma presentativo) ne pripisuje estetske vrednosti, za razliko od afektivnega (afectivo), ki vzpostavlja (»čustveni«) stik in sklepa pripovedni pakt z bralcem $(1957,114,117)$ ter je od vseh najbolj literaren (umetniški).

Da povsem razumemo ta "prag «, moramo poznati okoliščine izdaje romana, ki jih (skladno!) pojasnjujeta literarna zgodovina in šesti predgovor (VI). Pred IV. poglavjem četrtega $\mathrm{zvezka}^{8}$ je namreč paratekst, njegov naslov (»Rokopis«) pa se pravzaprav nanaša na celotno romaneskno besedilo $\mathrm{v}$ nadaljevanju in ne le na sam paratekst:

katerega avtor je (literarna) oseba iz romana (Genette, 1987, 187-199). Najpogosteje je to junak, ki je sicer prvoosebni pripovedovalec romana, kar velja za Periquilla.

6 Inkvizicija je bila v španskem imperiju ukinjena leta 1813, a jo je Ferdinand VII. leta 1815 obnovil. Dokončno jo je leta 1834, v obdobju regentstva, ukinila Marija Kristina Burbonska. Omemba (ne)svobode tiska in inkvizicije se nanaša na prepoved izdaje četrtega zvezka v tem obdobju.

7 Sklicujem se na integralno različico iz leta 1830 (gl. zgoraj), vsi citati iz romana, ki jih zaznamujem samo s številko strani v oklepaju, pa so iz izdaje v Cátedri (Lizardi, 2008). 
"Manuscrito / Que el autor dejó inédito por los motivos que expresa en la siguiente / Copia de los documentos [...] «. Pred »sporna" poglavja je namreč umeščen prepis korespondence med Lizardijem in cenzorjem iz oktobra 1816, iz katere je razvidno, da je cenzor četrti zvezek pripustil v tisk, ki ga je prepovedal šele t. i. alcalde del crimen, sodni uradnik kazenskega oddelka, zadolžen za drugostopenjsko cenzorsko presojo (720).

Objava dovolila za izdajo na začetku knjige je bila do konca 17. stoletja, ponekod pa še kasneje, ustaljena praksa. Po logiki stvari je to veljalo le za dovolila, ne pa tudi za prepovedi, saj prepovedano delo ni šlo v tisk. Uradni dokument - ki je v prvem primeru fizično v knjigi, v drugem pa npr. v arhivu urada ali sodišča, torej je od knjige fizično ločen ${ }^{9}$ - je paratekst, saj romaneskni tekst zastopa in mu zagotavlja (oziroma onemogoča) obstoj. Primer Periquilla Sarnienta pa ni emblematičen zato, ker »epitekst postane peritekst «, temveč ker uradni akt, opremljen s (kritičnim) komentarjem, dobi funkcijo predgovora. ${ }^{10} \mathrm{Ni}$ le uredniški peritekst, ki zadeva materialnost izdanega teksta (platnice, kolofon ipd.), pač pa delom romana od četrtega zvezka dalje zagotavlja prezenco ter vsebuje vrednostno sodbo - o taistih delih romana in hkrati o njegovi recepciji: med drugim pravi, da Lizardijeva korespondenca s cenzorjem izkazuje »la arbitrariedad del gobierno español en esta América « (270). V odnosu do romanesknega besedila gre torej, $\mathrm{z}$ nekaj terminološkega rigorizma, za metaparatekst, pomembnejše od te formalne ugotovitve pa je dejstvo, da napeljuje k drugačnemu branju odlomkov, ki mu sledijo -

" 'Nunca creí que los negros fueran capaces de tener almas tan grandes.' (725) ¿Cómo cumpliré bien los preceptos de aquella religión que me obliga a amar al prójimo como a mí mismo, y a no hacer a nadie el daño que repugno, comprando por un vil interés a un pobre negro, haciéndolo esclavo de servicio, obligándolo a tributarme a fuer de un amo tirano, descuidándome de su felicidad y acaso de su subsistencia, y tratándolo, a veces, quizá poco menos que bestia?' «(728-729) 11

-, pa tudi $\mathrm{k}$ drugačnemu branju romana kot celote; pa ne le $\mathrm{v}$ določenem zgodovinskem trenutku. Ne bi bilo prvič, da je bil učinek cenzure diametralno nasproten

9 Po Genettu peritekst in epitekst $(1987,11)$.

10 Ravno pri predgovoru zaradi njegove heterogenosti velja, da mu status predgovora podeljujejo krovne naloge, ne pa (zgolj) - ali celo sploh ne - formalni kriteriji (cf. Genette, 1987, 17).

11 »Nikdar si nisem mislil, da so črnci lahko tako velikodušni.« / »Kako naj spoštujem zapovedi vere, ki mi veleva, naj ljubim svojega bližnjega kakor samega sebe in naj nikomur ne storim žalega, obenem pa naj iz podlega koristoljubja kupim ubogega črnca, si ga napravim za sužnja, ga prisilim, da se mi klanja kot tiranu, se požvižgam na njegovo srečo ali celo preživetje in ravnam z njim katerikrat malodane kot z živino?« 
želenemu. ${ }^{12}$ Šesti predgovor k neobjavljenemu delu romana je torej zares predgovor, njegova popolna neliterarnost pa je (sploh če pomislimo na vsebino spora) avantgardna: vključen v literarno delo ta »antiliterarni« uradni dokument ustvarja protiučinek.

Prepis korespondence, spremni dopis in umestitev $\mathrm{v}$ roman so lahko delo (resničnega) urednika integralne verzije iz leta 1830 (avtentično alografski predgovor), lahko pa da tudi tu Lizardi prevzema vlogo »zgolj urednika« in je bilo vse troje njegovo delo (psevdoalografski predgovor); morda s korespondenco vred. Kakorkoli že, identiteta »odgovornega« za ta predgovor očitno nima bistvenega pomena za učinek, ima pa ga za literarno kritiko - ki pač mora priznati, da je »odgovorni« ravnal premeteno.

\subsection{Predgovor in fikcija}

Doslej obravnavana predgovora imata poleg enake tipologije še eno skupno lastnost: sta "resna«, oziroma dokumentarna in dokumentirana ter nista niti literarna (tj. umetniška) niti fikcijska (tj. izmišljena). ${ }^{13}$ Toda že v drugem in tudi zadnjem stavku kratkega »Nujnega opozorila « Lizardi uporabi prijem, za katerega to ne velja povsem: dodaja namreč, da si v nadaljnjih predgovorih pridržuje pravico do krajšanja in raznih prilagoditev, kar bo, »če to želi in zmore, zvedavi bralec opazil« (87).

Predgovor kot prag postane literarno zanimiv, ko dobi prizvok, kot bi dejal Genette, »oficielne fikcije« $(1987,185)$ : od bralca se ne pričakuje, da ji bo verjel, hkrati pa za njeno razkritje nima nobenega interesa, ker (postopoma) pristaja na (kratkomalo) fikcijo. ${ }^{14}$ Navedeni stavek je namreč paradoksalen, če upoštevamo, da ga je zapisal Lizardi: po eni strani prvi predgovor priča o avtentičnih okoliščinah, po drugi strani pa se spaja s funkcijami naslednjega, psevdoalografskega predgovora. ${ }^{15} \mathrm{Da}$ "Nujno opozorilo« skuša biti prav takšno, torej vidimo šele, ko preberemo oba oziroma vse predgovore, ki formalno ali tipološko ustrezajo tem proporcem.

Napovedani naknadni posegi v ostale predgovore (predgovore, ne le rokopis) pa pomembno vplivajo na poetično in retorično podobo literarnega dela. Okrog drugega

12 Genette govori o "performativni moči« parateksta (Genette, 1987, 17).

13 Resnost bi kot režim parateksta lahko izpeljali iz Genettove teorije transtekstualnosti, na kateri temelji tudi paratekstualnost: npr. plagiat je resna imitacija, pastiche pa ludična (cf. Genette, 1982). Genette pri predgovorih sicer izenači »ludično« in »fikcijsko» $(1987,280-281)$.

14 Genette očitnih razlik v tonu prevzemalnih avtentično avktorialnih predgovorov, ki jih ima sicer za predgovore par excellence $(1987,182)$, posebej ne opiše. Lizardijev predgovor k Periquillu Sarnientu in Galdósov k Misericordii, ki je naturalistični ekspozé o eksperimentalnem romanu (cf. Zola, Vzpon Rougonovih; predgovora se ujemata celo v nekaterih formulacijah), sta tipološko identična, a le Lizardijevemu lahko pripišemo literarnost, ne pa tudi, po Genettovem mnenju, fiktivnosti: kvečjemu status »oficielne fikcije».

Gl. 4.3. 
(II), tretjega (III), četrtega (IV) in petega (V) izgrajuje prvi predgovor (I) nekakšen okvir. ${ }^{16}$ Iz predgovora v predgovor izvemo več o osebi, ki se ji imamo zahvaliti, da je roman ugledal luč sveta. V njej najprej vidimo zgoraj opisano »oficielno fikcijo«, toda na koncu romana bo Periquillo (ki še vedno pripoveduje na smrtni postelji) pojasnil, kako so ga obiskovali številni prijatelji, med njimi »neki Lizardi«, poznan pod nadimkom Mehiški mislec, v Španiji pa osovražen: »autor desgraciado en vuestra patria y conocido del público con el epíteto [...] del Pensador Mexicano« (920). Gre torej za projekcijo Joséja Joaquína Fernándeza de Lizardija, El Pensadorja, nakazanega avtorja, o katerem bo Periquillo v romanu "s svojo običajno naivnostjo « povedal, da je neizobražen in netalentiran, a zagotovo poštenjak in dober človek. Še več, po Periquillevih besedah je ideal razsvetljenskega človeka: "sé que no es embustero, falso, adulador ni hipócrita. Me consta que no se tiene ni por sabio ni por virtuoso; conoce sus faltas, las advierte, las confiesa y las detesta. Aunque es hombre, sabe que lo es. «Periquillo ga je celo že tisočkrat slišal govoriti o lastnih napakah, se zavestno in odgovorno soočati z njimi in jih obžalovati (920).

Zato mu tik pred smrtjo odstopi svoj (avtobiografski) rokopis in mu poveri nalogo urednika, pa tudi (nadaljnjega) biografa: »En ese instante dejé a mi amigo el Pensador mis comunicados y estos cuadernos para que los corrija y note, pues me hallo muy enfermo..." Sledijo torej »Notas de el Pensador«, ki od Periquilla prevzame pripovedovanje in nadaljuje: »Hasta aquí escribió mi buen amigo don Pedro Sarmiento, ${ }^{17}$ a quien amé como a mí mismo, y lo asistí en su enfermedad hasta su muerte con el mayor cariño« (921). Manever lahko opišemo s Periquillem kot dramatiziranim zanesljivim pripovedovalcem, ${ }^{18}$ skozi katerega se implicitni avtor prikaže v najlepši moralni luči in za konec iz sebe ustvari dramatiziran lik - (novega) pripovedovalca, da bi to podobo utrdil. Toda taisti Lizardi cum El Pensador cum nakazani avtor cum ekstradiegetični heterodiegetični cum intradiegetični homodiegetični pripovedovalec je že v četrtem predgovoru oksimoronično pripomnil, da je Periquillev rokopis »obra romancesca«, torej roman, in da je v romanih pomembnejša »la acción « kakor »la moral explicada $\lll(99)$.

Vprašanje, »kaj je roman«, je v romanih 18. stoletja zelo pogosto in izhaja predvsem iz tedanje nedorečenosti romana kot zvrsti in posledičnega slovesa

16 S še nekaj terminološkega rigorizma: metaekstradiegetični.

17 Pedro Sarmiento je junakovo pravo ime. Na začetku pripovedi je pojasnil, da so mu nadimek Periquillo (šp. "papagajček «) nadeli v šoli, ker je nosil zeleno suknjo in rumene hlače, drobna sprememba priimka pa je nastala iz posmeha med sošolci, ko je dobil garje (šp. sarna; "garjav« je v evropski španščini sarnoso, v južnoameriški španščini - ali, natančneje, v Gvatemali in Mehiki - pa sarniento (DRAE)).

18 Zanesljivi pripovedovalec "govori ali ravna v skladu z normami danega dela (tj. nakazanega avtorja)« (Booth, 2005, 135). 
neresnosti, manjvrednosti, celo škodljivosti. Sloves ni vplival na priljubljenost, je pa povzročil, da je pogostejša od izjave »to je roman « postala trditev »to ni roman, temveč resnična korespondenca etc." oziroma »rokopis«, ki ga avtor, skrit za uredniško masko, popravi in da objaviti, tako kot v primeru Periquilla Sarnienta. Prostor za razprave o avtentičnosti in verodostojnosti je bil ravno predgovor, a je namesto "pogodbe o verodostojnosti « avtor z bralcem pogosteje sklepal "pogodbo o fikciji «(Genette, 1987, 210), predvsem če je mogoče že iz paratekstualnih indicev razbrati toliko protislovij. A tudi če sta želja po avtentifikaciji in metafikcijskost znak modernega pripovedništva, ne moremo reči, da nista v 18. stoletju tudi sami postali nekakšna konvencija - v Lizardijevem primeru pa zagotovo naznačujeta vpliv še enega modela: Don Kihota. ${ }^{19}$

Omembe vredno je zlasti to, da je avtentifikacijo, ki je zrasla iz pripovedne tehnike, Lizardi uporabil še za »ideološko« avtentifikacijo: ko si Periquillo in Lizardi prijateljsko podata vlogo pripovedovalca, se postavita ne le na isto diegetično raven, temveč tudi $v$ isto stvarnost, ki je, če se spomnimo prvega predgovora, »oficielna fikcija«, pri tem pa drug za drugega vseskozi jamčita, da sta »dobra človeka « - čeprav slaba pisca. ${ }^{20}$ Mogoče "predgovorni aparat« v Periquillu Sarnientu ravno zato do potankosti razumemo in osmislimo šele, ko roman preberemo do konca in podrobneje slišimo o prijateljstvu med Periquillem Sarnientom in (»nekim «) Lizardijem z nadimkom El Pensador. ${ }^{21}$

\subsection{Avktorialni predgovori in »dva bralca»}

Stik z bralcem v predgovoru ni le tradicija in konvencija, pač pa, sine qua non, njegova poglavitna funkcija. ${ }^{22}$ Predgovor, ki je tako naslovljen, a je v resnici posvetilo, zato ni predgovor, ${ }^{23}$ po analogiji torej preliminarni paratekst, ki je naslovljen kot posvetilo, a je po vseh indicih, najprej pa po navezovanju stika $\mathrm{z}$ bralcem, predgovor, beremo (in »obravnavamo«) kot predgovor. Predgovori (II), (III) in (IV) namreč nosijo skupni (nad)naslov »Prólogo, dedicatoria y advertencias a los lectores«; drugi predgovor (II) je avktorialni in je večinoma dialoška polemika s »prijateljem«, komu posvetiti delo - a je mnogo več kot to, zlasti pa, kljub (nad)naslovu, ni posvetilo.

19 O Cervantesu in Lizardiju gl. npr. Gónzalez-Cruz, 1974.

20 Shema pripovedovalcev zelo spominja na Unamunovo Meglo - oziroma, po logiki stvari, obratno.

21 Merim še na številne faktografske podrobnosti, ki jih tu ne omenjam, npr. kdo je Carlos iz drugega predgovora (90) etc. Konec koncev tudi Cervantesov predgovor - »aunque parezco padre, soy padrastro de don Quijote« $(2009,7)$ - povsem razumemo šele, ko izvemo za Cida Hameteja Benengelija; kar pa je povezano s pripovedno tehniko in ga za primer daje tudi Booth $(2005,177)$.

22 Nesporno stičišče vseh študij, ki se neposredno ali posredno ukvarjajo s predgovorom: Porqueras Mayo (1957), Genette (1982; 1987), Iser (1994), Caturla Viladot (2005) idr.

23 Cf. Porqueras Mayo (1957, 112), ki temu pravi prólogo-dedicatoria: npr. »Prólogo a la muy alta y muy poderosa señora doña Juana, Infanta de Castilla« je »zgolj« posvetilo. 
Prične se z nagovorom: "Señores míos: Una de las cosas que me presentaban dificultades para dar a luz la Vida de Periquillo Sarniento, era elegir persona a quién dedicársela. Kot pravi, njegova skrb, komu posvetiti roman, izvira iz tradicije »leí en un librito viejo« -, kajti vsako delo, ki kaj velja, ima pokrovitelja; to da je »costumbre continuada« (89), zato avtor prijatelju potoži, da Periquillo Sarniento ne more ostati brez posvetila (90). Po nasvetu »prijatelja « sklene, da bo roman posvetil bralcem, ki bodo ne nazadnje pokrili stroške tiska: "¿A quiénes con más justicia debes dedicar tus tareas, sino a los que leen las obras a costa de su dinero? «Zdaj se bralcem, ki so »najzanesljivejši meceni«, avtor sklene dobrikati, to je namreč »usanza de las dedicatorias« (93). Da »bralca delo stane«, je sicer pogost topos npr. v baročni dramatiki, kjer ima občasno izrazito žaljivo konotacijo: bralec (oziroma gledalec) ${ }^{24}$ resda lahko raztrga delo in avtorja, toda le slednjemu bo pripadlo maščevalno zadoščenje, ker je bralec moral za kaj takega najprej seči v žep (Porqueras Mayo, 1957, 143). ${ }^{25}$ Tako se Lizardi bralcem prične dobrikati šele, ko ugotovi, da se mu to izplača, pomenljiv pa je, kar zadeva njegovo mnenje o bralstvu, tudi zamolk, zaznamovan $s$ tropičjem: »esta pequeña obrita que os ofrezco como tributo debido a vuestros reales... méritos«(95).

Kot že omenjeno, psevdoalografskost drugega predgovora - torej dejstvo, da $E l$ Pensador ne priznava avtorstva romana - sprva ni povsem jasna. Zato tudi ni povsem jasno, da topos lažne skromnosti leti nanj kot na prijatelja urednika, ne kot na pisatelja: "aunque soy limitado, y por lo mismo, de mis tareas no se puede esperar ninguna cosa sublime, sino bastante humilde y trivial, créeme, esta obrita me ha costado algún trabajo, y tanto más, cuanto que soy un chambón« (93), tudi če romanu pravi »mi obrita

$\mathrm{Ni}$ tako pomembno, ali je ta dvoumnost načrtna ali stvar pripovedne nekonsistentnosti; $\mathrm{v}$ Lizardijevi rabi toposa je namreč pomembna novost. $\mathrm{V}$ enakosti vseh bralcev, katerih naklonjenost si skuša pridobiti, prepoznamo vsebinsko permeabilnost ${ }^{26}$ predgovora k romanu, ki bo zagovarjal enakost vseh ljudi: »Sé que acaso seréis algunos plebeyos, indios, mulatos, negros, viciosos, tontos y majaderos. Pero no me toca acordaros nada de esto, cuando trato de captar vuestra benevolencia y afición a la obra que os dedico« (94). ${ }^{27}$ Takšna vsebinskost (in ne le tematskost) daje toposu

24 Objava igre v tiskani obliki je bila namreč kasnejša od uprizoritve. Primere tega toposa najdemo tudi pri Shakespearu, npr. v prologu k Henriku VIII.

25 Porqueras Mayo se glede topike v predgovoru (1957, 142-144) opira na Curtiusa (2002).

26 Eno ključnih značilnosti predgovora, permeabilnost, utemelji Porqueras Mayo $(1957,100)$ : „El prólogo recibe, por su proximidad al libro que acompaña, unas marcadas influencias que lo atraviesan, modelan y transforman. Su carácter introductorio a algo, hace que este algo se prolongue hasta él y le revista de sus características."

O podobi temnopoltega človeka pri Lizardiju gl. Bueno, 1972. 
nov smisel, rekontekstualizacija toposa pa predgovor osvobaja konvencionalnosti, $\mathrm{v}$ katero so ga $\mathrm{v}$ dolgi literarni tradiciji potisnili prav topoi.

Primer »dveh bralcev« se nadaljuje v »Predgovoru pod krinko zgodbe« (V). Pisatelja, ki pod večer s peresom v roki ${ }^{28}$ za objavo pripravlja drugi zvezek romana, obišče "prijatelj po imenu Védenje [Conocimiento], možak častitljive starosti in bogatih izkušenj « (291): gre za dialog z alegorično osebo. ${ }^{29}$ Pisatelj urednik poprosi, naj mu pove, kaj bralstvo meni o prvem zvezku, in prijatelj najprej odgovarja s pitijsko parafrazo »bistrega in neukega bralca«: »es menester advertir que el público es todos y ninguno, que se compone de sabios e ignorantes, [...] que es moralmente [sic!] imposible contentar al público, esto es, a todos en general « (291-292). Klasični model tega predgovora ustreza tudi neoklasicistični vsebini in slogu: alegorična oseba svoje mnenje utemelji z Iriartejevo basnijo ${ }^{30}$ o plešočem medvedu: "Si el sabio no aprueba, malo; / si el necio aplaude, peor « (293). Šele nato na pisateljevo prigovarjanje dialog zapelje v drug topos - parafrazira najbolj jedke kritike, tako pa lažno precenjevanje bralca in lažno skromnost (avtorja urednika) iz drugega predgovora (II) spremeni v izrazito exusatio propter infirmitatem ${ }^{31}$ - ter spet nazaj, rekoč, da kritike prihajajo le od »aquéllos a quienes les amargan las verdades que usted les hace beber en la copa de la fábula « (294). ${ }^{32}$

Diametralno nasprotna vrednotenja bralstva pa imajo vendarle enotno funkcijo, tako kot ima delitev na bistre in neuke bralce dve implicitni sporočili. Prvič, bralec je bister ali neuk ter hkrati te ali one rase oziroma stanu, razlikovanji pa nista povezani. In drugič, vsak bralec, bister ali neuk, se bo samoumevno hotel poistovetiti z bistrim. Če se ne more, zdaj ve, kaj mu je storiti: roman naj bere $\mathrm{z}$ več naklonjenosti.

\section{5 (Anti)pikareska in razsvetljenstvo}

\subsection{El Periquillo Sarniento in pikareska}

Čeprav imajo avktorialni predgovori skoraj svojo fabulo (»El Pensador in vsi njegovi prijatelji«), šele v petem predgovoru (V) alegorija Védenja naravnost pove, kaj si bralstvo misli o Periquillu kot avtobiografskem pripovedovalcu: da je pretirano zgovoren, da je zajedljiv kritik in da jim njegova pedagoškost preseda. »Dicen que este Perico habla más de lo que se necesita [...], que quién lo ha metido a pedagogo del

28 Cf. Cervantes, 2009, 8.

29 Kot »izvajalec« dramskega prologa se alegorična oseba (ali božanstvo) pojavi v atiški dobi.

30 Tomás de Iriarte (1750-1791), najpomembnejši španski basnopisec iz obdobja neoklasicizma.

31 Po Genettovem mnenju je izmed obeh ta topos učinkovitejši $(1987,211)$.

32 »Fábula« tu s pomenom »zgodba«, ne »basen«. 
público para, so color de declamar contra los abusos, satisfacer su carácter mordaz y maldiciente« (294). Zgoraj pišem o predgovorni funkciji, izpeljani iz te kritike, ki leti na »urednika«, na roman in na samega Periquilla. Pomembna je zato, ker je vsaka avktorialna, aktorialna ali alografska sodba ali informacija o Periquillu v samem romanu indic, $\mathrm{v}$ kolikšni meri on ustreza podobi pícara in roman pikaresknemu. ${ }^{33}$ Ta je bil kot žanrski okvir za moralno didaktične namene razsvetljenskega romana predvsem »modelo fácilmente organizable« (Ruiz Barrionuevo, 2008, 36) oziroma »an indefinitely adaptable framework for a long comic novel« (Close, 2003, 18), zasluge zanj pa ima (anonimni) avtor Lazarčka s Tormesa, ki si je zgodbeni okvir izposodil pri Apuleju. Ne nazadnje pa sta bili prestižnost in dolga tradicija pikareske v zavesti vsakega špansko pišočega avtorja, ne le Lizardija.

Pikareskni roman zaznamujejo epizodičnost, avtobiografskost, prvoosebnost in razvojna pot protagonista, od vzporednih zvrsti, na prvem mestu Bildungsromana ki je buržoazen in konformističen -, pa ga ločujejo družbene in značajske lastnosti pícara, na prvem mestu njegov odnos do družbe. Pícaro prihaja s socialnega dna in se ne poskuša prilagoditi ali sprejeti (»družbenotvornih«) vrednot, marveč jih zavrača in kritizira. Resda je satirični hiperkriticizem lahko tudi razsvetljenski, a pod pogojem, da je humanistično naravnan. Toda v pikareski preraste $\mathrm{v}$ absurd, pícaro je antijunak, njegovo življenjsko vodilo pa je znajti se in preživeti v sovražnem svetu, kjer ne sme zaupati nikomur: »The picaresque novel, then, presents a perverted educational process « (Close, 2003, 18). Rico (2000) in Carreter (1972) v splošnem menita, da zato vse pripovedne sestavine pikareske služijo ali razlagi ali sprotnemu upravičevanju pícarove situacije in njegovega ravnanja. Od tod tudi apologetskost (avktorialnega) predgovora, saj se prologist podzavestno poistoveti s pícarom. ${ }^{34}$

Pri Lizardiju se zgodi ravno obratno: roman v resnici pripoveduje o razvoju pícara v razsvetljenskega človeka, a čeprav je izhodišče za izgradnjo lika res pícaro, je že iz Periquillevega (aktorialnega, (III)) predgovora odmik od pikareske takoj jasen: "cuando les refiero tal cual acción buena que he practicado, no es por granjearme su aplauso, sino por enamorarlos de la virtud« (96). ${ }^{35}$

\subsection{Aktorialni predgovor in antipikareska}

Tudi v pikaresknem romanu vsako epizodo spremlja nauk, ki pa je praviloma enoten: kako se znajti še bolje. Moralistična nota je, če že, vselej mračna in ima pogosto teološko ozadje. Guzmána de Alfaracheja, denimo, je doletela pravična kazen in svojo

33 O Periquillu Sarnientu in pikareski gl. npr.: Béroud, 1979; García de Paredes, 1972; Polić Bobić, 1988.

34 To poudarja tudi Porqueras Mayo $(1957,101)$, ki s tem primerom utemeljuje permeabilnost predgovora.

Kurziva je moja. 
zgodbo pripoveduje na galeji, kar Alemán v uvodnem pojasnilu izrecno postavlja za nauk: »Y no es impropiedad ni fuera de propósito si en esta primera escribiere alguna dotrina (Alemán, 1997, 113). ${ }^{36}$ García de Paredes (1972) v Alemánovi rabi pikareskne forme vidi didaktične in religiozne razloge, medtem ko se je Lizardi okvira poslužil z mislijo na filozofsko in socialno reformo. Tudi Quevedov Buscón se konča, ko se Pablos na begu pred roko pravice vkrca za Ameriko in se sprašuje, ali mu bo na drugi celini in v drugačnem svetu kaj bolje, vendar kataforično doda: »Y fueme peor, como V. Md. verá en la segunda parte, pues nunca mejora su estado quien muda solamente de lugar y no de vida y costumbres« (Quevedo, 1990, 308).

Moralistični poskusi v pikareski torej zaradi socialnega determinizma in teološke podstati (Salomon, 1988, 422) niso neoklasicistični docere delectando oziroma vzgojna družbena satira razsvetljenskega Periquilla Sarnienta, ki se na pikaresko opira samo formalno. Pa tudi formalna sprememba je odraz idejne podstati: pikareskni predgovor je avktorialni, v Periquillu Sarnientu pa je moralna tematika - ali pač topika prestavljena $\mathrm{v}$ aktorialnega. Periquillo kot lik in še eksplicitno, kot pripovedovalec, prevzema odgovornost za svoja dejanja, kar je znak modernega junaka in nič več pikaresknega (anti)junaka: v modernem romanu namreč »characters take conscious responsibility for their past life and act under its influence in each and every one of the decisive moments of their existence (Carreter v Close, 2003, 19). Pomembna funkcija predgovora je opozarjanje na koristnost, toda koristnost vsebine in snovi romana (Genette, 1987, 202-203); pri Periquillu Sarnientu pa tudi (aktorialnega) predgovora.

Periquillo sam dodaja, da je njegov predgovor »tapaboca « in »remedio anticipado del libro« (96). Genette tej funkciji pravi »strelovod « $(1987,211)$, ki nevtralizira kritike in skrivoma poveličuje pisca, vendar lahko opazimo, da Periquillev poanto razširi in vanjo pritegne še bralca ter ga, ko meri na njegovo perceptivnost, poskuša omajati in celo senzibilizirati: "Pero aun cuando todo el mundo lea mi obra, nadie tiene que mosquearse cuando vea pintado el vicio que comete, ni atribuir entonces a malicia mía lo que en la realidad es perversidad suya « (97). Zdi se, da je v predgovorih prav ta bistroumna neapologetskost ${ }^{37}$ znak ne zgolj prikrite samohvale, ampak tudi moderne pripovedi - najmanj pa pomeni prelom s tradicijo, ki bi sicer kot apologijo jemala opažanje, da so okusi pač različni, da »no hay cosa buena que no proceda de las manos

36 Kurziva je moja.

37 Zanimivi so ravno estetski odtenki te iste funkcije predgovora, cf. npr.: »No hay palabra mala si no es a mal tenida « (Juan Ruiz, Libro de buen amor); "No quiero irme con la corriente del uso, ni suplicarte casi con las lágrimas en los ojos, como otros hacen, lector carísimo, que perdones o disimules las faltas que en este mi hijo vieres « (M. de Cervantes, Don Kihot); »There is no such thing as a moral or an immoral book. [...] Those who go beneath the surface do so at their peril« (O. Wilde, The Picture of Dorian Gray) ali celo: "Persons attempting to find a motive in this narrative will be prosecuted; persons attempting to find a moral in it will be banished; persons attempting to find a plot in it will be shot" (M. Twain, The Adventures of Huckleberry Finn). 
de Dios, ni tan mala de que no le resulte alguna gloria (Alemán, 1997, 111) in da se v vsaki knjigi najde kaj, kar bo bralcu v zabavo. ${ }^{38}$ Če se še enkrat vrnemo k »dvema bralcema«, je alegorični sogovornik iz petega predgovora tu nedvoumen: avtor naj se nikar ne nadeja, da bodo Periquilla hvalili tisti, ki se bodo prepoznali v njegovih kritikah:

"¿Quiere usted que hable bien de Periquillo un mal padre de familias, una madre consentidora de sus hijos, un preceptor inepto, un eclesiástico relajado, una coqueta, un flojo, un ladrón, un fullero, un hipócrita, ni ninguno de cuantos viciosos usted pinta? No amigo, éstos no hablarán bien de la obra, ni de su autor en su vida« (295).

Slab in nemoralen človek bo torej nenaklonjen bralec. Ali celo didakti(cisti)čni obrat toposa: kdor bo bral z naklonjenostjo, že ni slab in nemoralen.

\section{Sklep}

Novejša literarnozgodovinska dognanja kažejo, da kljub zapoznelosti in skromnosti $\mathrm{v}$ primerjavi $\mathrm{z}$ anglo-francoskim kulturnim prostorom španska romaneskna produkcija nikakor ni le tradicionalistično imitativna. ${ }^{39}$ Zaradi »dvojne perifernosti« kolonij in ostalih družbeno-zgodovinskih dejavnikov smemo trditi, da Periquillo Sarniento ustreza proporcem (evropskega) romana 18. stoletja. Da pikareskni okvir prerašča, ugotavljajo številne študije; na nekatere se opiram v pričujočem članku, s katerim pa sem želel opozoriti na pomembno vlogo predgovora pri tem izmikanju tradiciji, kar se kaže na več načinov.

Predgovor se zaradi permeabilnosti v slogu, tonu in posebej idejah zgleduje po "svojem« romanu, čeprav je, paradoksalno, opredeljen na ontološki (in diegetični) ločenosti od njega. Vse to je razvidno iz sledov razsvetljenske misli že v samih predgovorih, kar je ključno tudi za odmik od pikaresknega romana. Ni le Periquillo "antipícaro", tudi predgovori odsevajo drugačne, "antipikareskne» vrednote in potrjujejo njihovo všečnost, saj si bralčeve naklonjenosti ne pridobiva niti z apologijo niti $\mathrm{z}$ besedami, da bodo "zgode in nezgode« v užitek in zabavo, marveč da bodo $\mathrm{v}$ korist, pri čemer bralca poziva zlasti k lastni kritični presoji. S pridobivanjem bralčeve naklonjenosti povezana topika nasploh dobro ponazarja, da nekdaj poglavitne funkcije predgovora ne temeljijo več na konvenciji, pač pa jo izrabljajo, da mu zagotovijo obstoj, a z njim tudi drugačno funkcionalno in literarno podobo. Dodajmo, da se

38 Cf. avktorialni predgovor k Lazarčku s Tormesa ali drugi od Alemánovih (avktorialnih) predgovorov h Guzmánu de Alfaracheju, »Al discreto lector«. Guzmán je lep primer »dveh bralcev«: prvi predgovor je namreč namenjen »Al vulgo«. 
zelo nepikareskni aktorialni predgovor od avktorialnih, ki so baročno gostobesedni, afektirani in redundantni, loči še po neoklasicistično jasnem slogu.

Prav tako pomembno je, da podobo implicitnega ali modelnega bralca, kakršnega terja, Lizardi ukroji po meri razsvetljenskega človeka in tesno poveže s pripovednimi manevri v predgovoru. Velja namreč tudi obratno: (moralno) dober človek je dober, torej perceptiven bralec. Njemu sta pravzaprav "posvečeni« - celo eksplicitno, če pomislimo na drugi predgovor! - ironija »oficielne fikcije« in kompleksna pripovedna struktura. Četudi je Wilde trdil, da knjiga nikdar ni moralna ali nemoralna, temveč le dobro ali slabo napisana, ne moremo zanikati, da (humanistično) tendenciozna ali (razsvetljensko) didaktična literatura temeljiteje doseže svoj namen, če je prepričljiva tudi umetniško.

\section{Bibliografija}

\section{Viri}

Alemán, M. de, Guzmán de Alfarache, Madrid 1997.

Cervantes, M. de, Don Quijote, Madrid 2009.

Fernández de Lizardi, J. J., El Periquillo Sarniento, Madrid 2008.

Lazarillo de Tormes, Madrid 1976.

Quevedo, F. de, Buscón, Madrid 1990.

\section{Literatura}

Béroud, C., La picaresca como única posibilidad literaria o El Periquillo Sarniento, v: La picaresca (orígenes, textos y estructura) (ur. Criado de Val, M.), Madrid 1979, str. 1941-1945.

Booth, W. C., Retorika pripovedne umetnosti, Ljubljana 2005.

Bueno, S., El negro en El Periquillo Sarniento: Antirracismo de Lizardi, Cuadernos Americanos CLXXXIII/4, 1972, str. 124-139.

Carreter, F. L., Lazarillo de Tormes en la picaresca, Barcelona 1972.

Caturla Viladot, A., A orillas del texto. Por una teoría del espacio paratextual narrativo (doktorska disertacija), Barcelona 2005.

Close, A. J., The Legacy of Don Quixote and the picaresque novel, v: The Cambridge Companion to the Spanish Novel. From 1600 to the Present (ur. Turner, H. in dr.), Cambridge 2003, str. 15-30.

Curtius, E., Evropska literatura in latinski srednji vek, Ljubljana 2002. 
El-Kadi, A., Utopía nacional, reforma y represión en El Periquillo Sarniento, Colorado Review of Hispanic Studies 2, 2004, str. 25-41.

García de Paredes, F., El Periquillo Sarniento y lo picaresco, Revista de la lotería 102, 1972, str. 41-47.

Genette, G., Palimpsestes. La littérature au second degré, Pariz 1982.

Genette, G., Seuils, Pariz 1987.

González-Cruz, L. F., Influencia cervantina en Lizardi, Cuadernos Hispanoamericanos 286, 1974, str. 188-203.

Iser, W., Der implizite Leser. Kommunikationsformen des Romans von Bunyan bis Beckett, München 1994.

Lamb, R. S., The Costumbrismo of the Pensador Mexicano and Micrós, The Modern Language Journal 35, 1951, str. 193-198.

Medrano Arce, L. S. de, La utopía en El Periquillo Sarniento, Dicenda. Cuadernos de Filología Hispánica 6, 1987, str. 509-523.

Polić Bobić, M., Žanrovski i prosvjetiteljski aspekti romana Josea Joaquina Fernandeza de Lizardija (doktorska disertacija), Zagreb 1988.

Porqueras Mayo, A., El prólogo como género literario, Madrid 1957.

Ramírez, E., Ilustración y dominación: El Periquillo Sarniento bajo el Siglo de las Luces, Revista de Humanidades: Tecnológico de Monterrey 21, 2006, str. 65-103.

Rico, F., La novela picaresca y el punto de vista, Barcelona 2000.

Ruiz Barrionuevo, C., Introducción, v: Fernández de Lizardi, J. J., El Periquillo Sarniento, Madrid 2008.

Salomon, N., La crítica del sistema colonial de la Nueva España en El Periquillo Sarniento, v: Historia y crítica de la literatura hispanoamericana. 1. Época colonial (ur. Goic, C.), Barcelona 1988, str. 421-427. 


\section{Ignac Fock}

\section{Tradicija, konvencija in modernost: predgovori $v$ prvem hispanoameriškem romanu}

Ključne besede: predgovor, paratekst, El Periquillo Sarniento, hispanoameriški roman, razsvetljenski roman, pikareskni roman, topos

Prispevek je študija o šestih predgovorih k delu J. J. Fernándeza de Lizardija El Periquillo Sarniento, ki velja za prvi hispanoameriški roman. Lizardi je sicer uporabil tradicionalni pripovedni okvir, špansko pikaresko, toda El Periquillo Sarniento, ki med drugim kaže številne vzporednice s Cervantesovim Don Kihotom, je nedvomno razsvetljenski roman. Čeprav je Periquillo spočetka prikazan kot pícaro, skozi vzgojni proces $\mathrm{v}$ zgodbi postane vzor moderne miselnosti in vrednot.

$\mathrm{V}$ svoji naratološki študiji avtor pokaže, da ta roman že predgovori jasno postavljajo izven obstoječih tradicionalnih okvirov pikaresknega žanra, pa tudi izven razumevanja predgovora kot pripovedne konvencije, ki je veljala v španskem zlatem veku. Lizardi namreč bodisi spremeni pripovedno strukturo predgovorov bodisi $\mathrm{v}$ njih prenovi in prilagodi konvencionalno, že v klasičnih prologih uveljavljeno topiko. Ta sprememba $\mathrm{v}$ formalnem in estetskem pogledu je nedvomno odraz modernosti pripovedne tehnike, glede na Lizardijeve izrazito vzgojne namene pa jo lahko vidimo tudi kot način vzpostavitve trdnejšega pakta $\mathrm{z}$ bistroumnim in rahločutnim bralcem, da bi ta postal dovzetnejši za miselnost in vrednote, ki jih zastopa roman. 


\section{Ignac Fock}

\section{Tradition, convention, and modernity: the prefaces to the first Spanish-American novel}

Keywords: preface, paratext, Spanish-American novel, El Periquillo Sarniento, Enlightenment novel, picaresque novel, topos

The present article studies the six prefaces to Fernández de Lizardi's El Periquillo Sarniento, which is considered the first Spanish-American novel. Lizardi used the traditional Spanish picaresque novel as a framework; however, El Periquillo, often compared to Cervantes's Don Quixote, is clearly a novel of the Enlightenment. Although initially a picaro, Periquillo's educational process leads him to become a paragon of modern thought and values.

Through a narratological study, the author points out that the prefaces themselves reflect how El Periquillo manages to evade the pre-existing traditions - of the picaresque genre as well as that of the preface as a narrative convention, especially throughout the Spanish Golden Age - either by changing their narrative structures or by reusing and somehow manipulating the conventional topoi, well known from the classical prologues. This formal, but also aesthetic, development of the preface is an indubitable sign of modern narrative technique and, given Lizardi's clear educational purpose, an additional means of establishing a firmer pact with the astute and sensitive reader in order to make him more susceptible to the system of values and ideas exposed in the novel. 